Ohly, Friedrich, Hohelied-Studien, Wiesbaden 1958.

Ohly, Friedrich, "Vom geistigen Sinn des Wortes im Mittelalter", in: ders., Schriften zur mittelalterlichen Bedeutungsforschung, Darmstadt 1977, S. 1-31.

Önerfors, Alf, "Philologisches zu Walahfrid Strabo", in: Mlat. J6. 7 (1972), S. 41-92.

Ovidius Naso, P., Metamorphosen, hg. u. übers. von Michael von Albrecht, Stuttgart 1994.

Rahner, Hugo, "De Dominici pectoris fonte potavit", in: Zeitschrift fur katholische Theologie 55 (1931), S. 103-108.

Riese, Alexander (Hg.), Anthologia Latina, Bd. 1, Leipzig 1869.

Ruhe, Ernstpeter, De amasio ad amasiam, München 1975.

Rupertus Tuitiensis, De gloria et honore Filit Hominis super Mattheum, hg. Hrabanus Haacke, Corpus Christianorum. Continuatio Mediaevalis 29, Turnhout 1979.

Schreiner, Klaus, "Er küsse mich mit dem Kuß seines Mundes", in: Hedda Ragotzky, Horst Wenzel (Hg.), Höfische Repräsentation, Tübingen 1990, S. 89-132.

Seneca, Epistulae morales ad Lucilium. Liber V, hg. u. übers. Franz Loretto, Stuttgatt 1988.

Singer, Samuel, Germanisch-romanisches Mittelalter, Zürich, Leipzig 1935.

Stehling, Thomas, "To Love a Medieval Boy", in: J. of Homosexuality 8 (1983), S. 151 170.

Steinen, Wolfram von den, Notker der Dichter und seine geistige Welt, 2 Bde., Bern 1948. Störmer-Caysa, Uta, Entrückte Welten, Leipzig 1998.

Stotz, Peter, "Dichten als Schulfach", in: Mlat. Jb. 16 (1981), S. 1-16.

Strecker, Karl (Hg.), Die Cambridger Lieder, 3. Aufl., Berlin, Zürich, Dublin 1966.

Venance Fortunat, Poèmes, hg. u. übers. Marc Reydellet, Bd. 2, Paris 1998.

Veyne, Paul, "Homosexualität im antiken Rom", in: Philippe Ariès (Hg.), Die Masken des Begehrens und die Metamorphosen der Sinnilichkeit, Frankfurt a. M. 1984, S. 4050 .

Vollmann, Benedikt Konrad (Hg.), Carmina Burana, Frankfurt a. M. 1987.

Vollmann, Benedikt Konrad, "O admirabile Veneris idolum - ein Mädchenlied?", in: Udo Kindermann (u.a., Hg.), Festschrift für Paul Xlopsch, Göppingen 1988, S. $532-543$.

Werner, Jakob, Beiträge zur Kunde der lateinischen Literatur des Mittelalters, Aarau 1905. Williams, Craig A., Roman Homosexuality, New York, Oxford 1999.

Ziolkowski, Jan, Alan of Lille's Grammar of Sex, Cambridge, Mass."1985.
Philipp SCHWEIGHAUSER

\section{Concepts of Masculinity in The Wife's Lament and Its Critical Literature}

One way of thinking about the new men's studies is to say that they are a reaction against unitary concepts of masculinity. As' Ulf Reichhardt and Sabine Sielke (1998: 569) point out in their introduction to a special Amerikastudien/American Studies issue on masculinities, the new men's studies tend to focus on the differences within the category of 'man' rather than conceptualizing man as a urified agent of patriarchal oppression. What may sound like an antifeminist backlash is in this view much rather a concern with issues of power. within the sexes that by no means denies the importance of interrogating power relations between the sexes. On the contrary, as various practitioners of men's studies (Brod 1987, Connell 1987) insist, the structures of subordination existing between different types of maculinities, for instance between 'straight' and gay men, not only reproduce structures of subordination between men and women, but are actually based on them.

This is where the notion of 'hegemonic masculinity' as developed in Connell's Gender and Power (1987), comes in. Hegemonic masculinity is that form of masculinity which is widely accepted to constitute the norm for what it means to be a man. It can be defined positively as including traits such as heterosexuality, bodily strength or technical competence or negatively as excluding forms of masculinity such as those of gay men, young men, or so-called effeminate men. As the term 'hegemonic' already implies, the relation between hegemonic masculinity and other, subordinated forms of masculinity is not primarily based on violenceeven though, as in gay bashing, it may involve violencebut it is a form of "social ascendancy achieved in a play of social forces that extends beyond contests of brute power into the organization of private life and cultural processes" (Connell 1987: 184). Connell lists religious doctrine, the mass media and welfare/taxation policies among other areas of life that are crucially affected by-the power differential between hegemonic and other types of masculinities (184).

A decisive move in Connell's argument is to link the structures of subordination existing between different types of masculinity to those existing between the sexes. Asking himself why the ideology of hegemonic masculinity exerts such a powerful influence over men even though few men actually correspond to that ideal, Connell comes up with an answer that relates the power differential between men directly to that between men and women: "the major reason is that most men benefit from the subordination of women, and hegemonic masculinity is the cultural expression of this ascendancy" (184f.). As Connell makes clear, hegemonic masculinity is therefore "always constructed in relation to various subordinated masculinities as well as in relation to women. The interplay between different forms of masculinity is an important part of how a patriarchal social order works" (183). What Connell describes here is probably most visible in discourses that link homosexuality with effeminacy. 
In what follows, I would like to apply Connell's insights about the problematic nature of unitary and exclusionary concepts of masculinity to a re-consideration of some of the critical literature that has been built up around the Old English poem usually referred to as The Wife's Lament. More particularly, I want to focus on the debate surrounding the gender of the poem's narrator. I will attempt to show how critical moves that do not stop short of emending the text in an effort to exclude the possibility of a female narrator, are based on unitary concepts of masculinity that affect both men and women in similar ways. Interpretations of The Wife's Lament tend to disagree on some of the most basic issues, such as the number of characters in the poem, or whether the text as it is transmitted is a fragment or not. ${ }^{184}$ A majority of critics, however, agrees that the poem reports the lament of a wife who is first left behind by her husband, who embarks on a sea-journey. She is then seized and commanded to stay in a grove dwelling under an oak tree ${ }^{185}$ From that unhappy abode, she curses those responsible for her present situation and laments her fate, comparing her lot to that of happy lovers and thinking back on the better days she had spent with her husband. The poem ends with the wife's gnomic statements about the sufferings of separated lovers. What can be called the standard reading of the poem is based on the assumption that the poetic speaker is identical with the woman confined to exile in the underground cave. ${ }^{186}$ As proponents of the standard reading are ready to admit, this interpretation of the poem does not dissolve all uncertainties about the story told. For instance, it remains unclear precisely why the woman has been banished to her miserable abode. Some seek the solution to this problem in lines $42 \mathrm{ff}$., where a "geong mon" (1. 42)r a young man, is introduced, who might be the wife's lover and the reason for her being punished with solitary confinement. This lover could or could not be identical with the "ful gemacne monnan" (1.18), the fully suitable man, the wife has found after the departure of her husband. ${ }^{187}$ As Anne L. Klink (1992: 50 ) has shown, such conjectures must, however, remain speculative.

A significant minority of critics has chosen not to try to compose a credible story around the wife's banishment and instead dispense with the assumption of a female protagonist and a female narrator altogether. The first to refute the possibility of a

${ }^{186}$ For a reviews of different interpretations of The Wife's Lament, see Renoir (1975: 2366.) and Klinck (1992: 49-54). For speculations on the number of characters involved in the poem, see Klinck (1992: 50) and Ahrens (1999).

Whentersdorf (1994) argues convincingly that the mysterious "eoroscræfe" (1.28) is in fact "an ancient pagan sanctuary that included a cave opening up into other caves, located at the foot or in the side of a cliff or hill, in a wooden area with a great oak on or near the top of the cliff or hill' $(372)$

${ }^{136}$ For a recent affirmation of the standard reading, see Wentersdorf (1994), who provides the following answer to the question concerning the gender of the narrator: "Detailed reexamination of the linguistic evidence regarding this question has confirmed the now traditional interpretation, that The Wife's Lament is indeed a woman's lamentation" (357)

${ }^{187}$ For interpretations along these lines, see Sieper (1915: 223) and Ahrens (1999). female narrator was L.L. Schücking, who already in 1906 claimed in his "Das angelsächsische Gedicht von der "Klage der Frau" that "all difficulties [of interpretation] dissolve easily once we relinquish the idea of a female lament, which only produces a hodgepodge of contradictions" (446). ${ }^{188}$ As all subsequent critics following in his footsteps, Schicking had to contend with the first two lines of the poem, which contain three forms with feminine endings, namely "geomorre" (sad) "minre" (my) and "sylfre" (self/own), that seem to suggest that the narrator is female. Schurcking's solution to the problem was simply to explain away the first two lines of the poem as additions by a scribe who did not understand the meaning of the text (447). According to Schücking, the poem actually began in line three before being corrupted by a scribe:

Hwætl ic yrmpa gebad, sippan ic up aweox

niwra oppe ealdra, no ma ponne nu. (Schücking 1906:447)

Furthermore, Schücking argues, all the terms of address that other critics take as referring to a husband or lover would suit better the voice of a male "wineleas wrecca" (1. 9), a friendless exile, commanded to stay behind while his chief went on a seajourney. In Schücking's reading, the poetic speaker is not an wife longing for her husband, but a retainer lamenting the absence of his chief. The mysterious "geong mon" of line 42 is in this reading not a lover, but refers to all those young men who suffer from a fate similar to that of the narrator.

The main problem with Schücking's interpretation concerns the sheer implausibility of his attempts to attribute the feminine inflections of the first two lines to a misunderstanding on the part of a scribe. For if the presence of a fernale protagonist and narrator is indeed as unlikely as Schücking claimshe even calls such a reading "impossible" $(440)$ then why should a scribe have added two lines that precisely suggest this very impossibility? Almost sixty years after Schücking's original contribution, Rudolph C. Bambas in an article entitled "Another View of the Old English "The Wife's Lament" (1963) tried to substantiate Schücking's thesis by asserting that a poem. narrated from the point of view of a woman would be a highly unlikely oddity within the corpus of Old English poetry (308). Bambas further insisted on the unlikelihood of a (male) Anglo-Saxon minstrel impersonating a woman (304). Rather than trying to explain away the first two lines, as Schücking did, Bambas suggests scribal errors as the cause for the words with feminine inflections and proposes to emend them. His essay ends as follows:

As much as possible, the copy of the Exeter Book should be allowed to stand, but the emendation of geomorre and minre sylfre to suit the masculine speaker intended by the poet is a necessity. The scholarly effort to sustain the concept of a feminine subject has been ingenious and learned but should yield to a simpler

${ }^{1{ }^{\prime}}$ All translations from Schücking (1906) are mine. 
and more probable interpretation of the poem. For another title perhaps "The Exile's Lament" would do. (309)

Apart from the apparent objection that any attempts at legitimating one's interpretation with recourse to an alleged authorial intention are at best dubious, it must also be said that Bambas's reading little more than replicates Schicking's and therefore suffers from similar limitations. The most ingenious case for a male narrator so far has been put forward by Martin Stevens in his article on "The Narrator of The Wife's Lament" (1968). In contrast to Schücking and Bambas, Stevens does not opt for textual surgery as a way of dealing with the ominous feminine endings, but instead proposes that "the feminine inflections may have nothing to do with the sex of the speaker" (74). Put briefly, Stevens argues that the feminine -re endings of the words in question do not signal natural but grammatical gender. His argument rests on the assumption that the grammatical gender of "sio" (lot/plight) is feminine. The inflection of minre is not feminine because the speaker is a woman, but because it agrees with the grammatical gender of sio. The same applies to sylfre, whose feminine inflection is due to grammatical agreement with minre. Finally, geomorre is not an adjective with a feminine ending, but an adverb (in Old English, most adverbs are formed by adding. $-e$ to an adjectival form), so that ful geomorre would have to be translated as 'veryr sadly.' Stevens's reading is far more sophisticated and grammatically accurate than either Bambas's or Schücking's. Nevertheless, it also has its problematic aspects, for it cannot entirely do without emendations - Stevens proposes to change sio to sio - and also crucially depends on the assumption that "sio" is feminine, which is controversial (Mitchell 1972: 232).

But what I am interested in is less the question of whether those who suggest a male narrator are right or not -1 tend to side with those favouring a female voice but find especially Martin Stevens's case for a male narrator compelling ${ }^{189}$ - than the language the claims for a male narrator are made in. The very undecidability of the debate about the narrator's gender should prompt us to ask what exactly makes a critic opt for one position rather than the other. In other words, what desires beside the striving for scientific accuracy or at least plausibility condition a critic's preference for one theory over the other? In what follows, I will attempt to demonstrate that it is in the rhetoric of the proponents of a male narrator that we find traces of a desire that precedes and exceeds the critic's desire to come up with a plausible interpretation of the text.

${ }^{10}$ Stevers has been challenged by Bruce Mitchell (1972), who does not regard Stevens's reading as impossible but concludes that "he relies on too great a combination of improbabilities" (232) of which Mitchell lists five (grammatical agreement of minre and sylfre with sio(e), emendation of siðe for sid(e), existence of a feminine noun sio, semantic necessity of emendation,

identification of geomorre as an adverb). Stevens has more recently been defended by Mandel

(1987), whose final sentence and interpretation of the poem's final two lines fits in smoothly with my claims concerning the now, men must behave rightly regardless of the attendant sadness" (173).
Ironically enough, what has prompted me to investigate structures of desire in Schücking, Bambas and Stevens is a passage in Bambas which raises this question in relation to the other critics, i.e. the majority of critics who uphold the female narrator thesis. Towards the end of his essay, Bambas writes, "The attractions of this view are considerable. It adds some range to a body of poetry that in theme is limited and monotonous and enables the modern mind to respond sympathetically to a culture in which women and a tender love story had a place after all, if only in one poem" (308f.). If this constitutes the desire of the other critics, what; then, I was led to ask, constitutes the desires of Schücking, Bambas and Stevens? We may turn to the first paragraph of Bambas's article to begin this investigation.

It is a commonplace observation that Old English secular poetry reflects the limited attitudes and interests of a primitive warrior culture. In such a culture, the only matters worth celebrating in verse are the affairs of heroic war chiefs and the brisk young men who follow them for gold and glory. The constant themes are the worth and dignity, the fortitude, loyalty, and generosity of the fighters who defend the tribe. Peaceable churis and slaves are hardly mentioned, and women are referred to so seldom and so briefly that the prominence given to the Danish queen, Wealkpeow in Beowulf is considered remarkable. (303) If a line of argument is referred to in a scholarly article as "a commonplace observation," we tend to expect the article to contradict that observation. Bambas, however, does exactly the opposite. On the very next page, he evokes precisely that image of a male-dominated society as he rules out the possibility of female minstrels: "From what is known of the transmission of poetry among the early Teutons, poems were recited or chanted by male scops or minstrels at drinking festivities from which women had withdrawn in good time. Of entertainment by female minstrels nothing is known" (304). Reading Bambas, one cannot help feeling that what underlies his attempts to dispense with a female narrator is a desire to preserve an intact and unified vision of the Anglo-Saxon world as a strongly masculine culture in which womeri occupied only marginal spaces. A canonical version of that vision can be found in Chadwick and Chadwick's The Growth of Literature (1932), where the "Heroic Milieu" is characterized as revolving around the activities of warfare and drinking, with horses and armour as the most precious possessions and courage, loyalty, and strength as the primary virtues. It is a vision that has become challenged at least since Dorothy Whitelocks Anglo-Saxon Wills (1930) and Doris Mary Stenton's The English Woman in History (1957); and it is a vision that has more recently come under fierce attack by feminist scholars because of its exclusion of any kind of female experience beyond passivity, endurance and suffering. - In fact, Helen Damico and Alexandra Hennessey Olsen in their introduction to New Readings on Women in Old English Literature (1990) single out Bambas's contribution as "the culmination of androcentricism progressing from nineteenth-century paternalism to twentieth-century misogyny" (1990: 14). That this vision of a unified masculine Anglo-Saxon culture does not only exclude women but also other forms of masculinity becomes apparent in Bambas's discussion of lines 21-23a: 
Blipe gebæro ful oft wit beotedan pæt unc ne gedælde remne deaðana, owiht elles;

In blithe demeanor we two had very often vowed that nothing but death alone would separate us two, nothing else;

What sounds very much like a marriage vow is explained by Bambas as follows: "Lines 21-23a [...] suit the fierce loyalty that existed between a chief and his follower" (305). If we put aside for a moment the unlikelihood of reciprocal vows of loyalty unto death between a chief and his follower and accept that these lines are spoken by a man to man, we must still account for the affectionate tone of the passage, which expresses feelings that go beyond the loyalty a retainer owes his chief. To put it bluntly, what strikes me as peculiar about Bambas's reading of the passage is precisely that these lines do not strike him as somehow 'queer.' While $I$ am not claiming that The Wife's Lament is in fact about homoerotic love, I propose that Bambas's exclusion of that very possibility in the face of this highly emotionally charged discourse between men is based on a model of hegemonic masculinity which does define itself against other forms of masculinity, such as gay men. In order to discount the possibility of a female narrator, Bambas seems to find it necessary to downplay the affectionate tone of the poem, so as to be able to read the speaker's emotions as based on his "fierce loyalty" and nothing else.

We can already see a similar mechanism at work in Schücking's article Anticipating and trying to pre-empt objections to his arguments for a male narrator, Schücking writes, "What can certainly not be held against our view is that the tone is too sentimental for a man" (447). What seerns at first sight a concession on Schücking's part that even Anglo-Saxon men were capable of emotions like sentimentality, turns into something different as we read what he has to say about proponents of the female narrator thesis. For Röder, who considers the speaker to be a wife who longs for her departed husbard and eventually finds him only to be hidden away because he fears for her safety, Schücking has nothing but ridicule: "Röder's plot, however, first of all suffers from a sentimentality that is somewhat too strong even for Anglo-Saxon standards" (441). What are we to make of this? Does Schücking mean to say that Anglo-Saxons of the tenth century were a particularly sentimental people? Certainly not. When he refers to Anglo-Saxon standards, he means those of the critics whose construction of a sentimental love-story does violence to the text. That Schücking identifies this type of criticism with a specifically British type of criticism becomes clear when he pours scorn over Stopford A. Brooke's interpretation of The Wife's Lament. Schücking begins by quoting from. Brooke's reading of lines $47 \mathrm{ff}$. and then (beginning with "etc.") adds his own comments: "Then ${ }^{190}$ with a rapid change she thinks of her husband as exiled from her. She is not angry with himand the whole of this passage is subtly thoughtbut full of tender womanliness, full of pity that he is deprived of her. She knows, he loves her still...but he who thinks her guilty and ye loves her, o what sorrow must be his?' etc. This is not Desdemona anymore, but much rather the bad melodrama of suburban London theatre and in that sense truly most 'modern in feeling.' (445) What surfaces in Schücking's disparagement of Röder and Brooke is a profound dislike not only of British criticism, but also of British cultural production, which he both considers to be too sentimental andone may reasonably conjectureeffeminate. More specifically, Brooke and Röder become the object of Schücking's scorn because their reading of The Wife's Lament impinges on Schücking's construction of Anglo-Saxon England as a purely martial society with archaic values, and in which neither the female voice nor sertimentality had a legitimate place. ${ }^{\mathrm{x} 1}$ So when Schücking denies that the tone of the poem is too sentimental for a man, he does not mean to say that men can be sentimental, too, but on the contrary tries to explain away the sentimentality, which would not fit the unitary and exclusionary concept of Anglo-Saxon masculinity he cherishes.

Let us finally turn to Martin Stevens's case for a male narrator. As I have already pointed out, Stevens's reading is far more subtle than either Schücking's or Bambas's, and it is certainly no coincidence that the editors of New Readings on Women in Old English Literature have singled out Bambas rather than Stevens as a glaring example for twentieth-century misogyny. Nevertheless, we can detect in Stevens traces of the same desire for a unified vision of Anglo-Saxon masculinity and Anglo-Saxon culture. Stevens's remarks on what others perceive as the highly emotional tone of the poem, for instance, do not only share Schücking's rhetoric of ridiculealbeit in a much more restrained fashionbut also Bambas's unwillingness or inability to even contemplate the possibility of homosexual desire: An amusing sidelight is the point that this very same poem which according to some commentators is such a subtle expression of a woman's feelings (one critic even interprets the "dawn-care" passage as "ungratified sexual passion") can be read as a man's monologue without requiring the change of a single word. (84) Maybe the real 'amusing sidelight' is that Stevens doesn't even consider to make what appears to be the most obvious link between the suggestion of "ungratified sexual passion" and his own reading of the poem as a man's lament for the absence of another man. As in Bambas, this possibility is excluded along with the presence of the female voice. But Stevens goes further than that. In a move that should remind us of Bambas, Stevens uses the apparent absence of female worlds of

${ }^{190}$ The quote from Brooke is English in the original. Schücking's comment (starting with "etc.") is translated by the author of this article.

${ }^{19}$ See Helen Damico and Alexandra Hennessey Olsen's (ed.) New Readings on Women in Old English Literature for recent attempts to "temper the narrowly martial image" (15) of AngloSaxon England. 
experience from Old English poetry ${ }^{192}$ to support his arguments against the female narrator thesis: "The fact is that the Old English poetic vocabulary in general yields little insight into what can be called exclusively a "woman's thoughts or feelings." And "The Wife's Lament" yields none at all" (84). It is in such passages that the desire for unitary models of masculinity shared by Schücking, Bambas and Stevens merges most clearly with a desire for unitary models of femininity, i.e. for a demarcation of "what can be called exclusively a "woman's thoughts or feelings." Such models are problematic because they are exclusionary and because they only very reluctantly allow for deviance from the norm. As Patricia A. Belanoff points out in her refutation of the argument that the vocabulary of The Wife's Lament does not suit a woman's voice: "Perhaps it is inappropriate for a woman to folga secan [seek service], but perhaps the very inappropriateness creates meaning in the poem and for the speaker" (1990: 197). While I find Belanoff's reading of The Wife's Lament as an exercise in the Kristevan semiotic highly problematic, I share her unwillingness to accept as given the rigid and unitary models of both masculinity and femininity that inform some of the criticism of The Wife's Lament. Maybeand this is what $l$ take to be an essentia convergence between gender studies and the new men's studieswe need a little less insight into what makes a woman a woman and a man a man than Schücking, Bambas, and Stevens still possessed.

\section{Sources}

Ahrens, Henry, "The Wife's Lament." The Wife's Lament: Old English and Translation, 1999. http://ucaswww mom.uc.edu/english/oe/wife/lament.html (10 May 2000).

Bambas, Rudolph C. "Another View of the Old English Wife's Lament." Journal of English and Germanic Philology, 62:2 (1963), pp. 303-309.

Belanoff, Patricia A., "Women's Songs, Women's Language: Wulf and Eadwacer and The Wife's Lament." New Readings on Women in Old English Literature. Ed. Helen Damico and Alexandra Hennessey Olsen. Bloomington and Indianapolis Indiana University Press, 1990, pp. 193-203.

Brod, Harry, "Introduction: Themes and Theses of Men's Studies." The Making of Masculinities: The New Men's Studies. Ed. Harry Brod. London etc.: Allen \& Unwin, 1987, pp. 1-17.

Brooke, Stopford A., History of Early English Literature: Being the History of English Poetry from It Beginnings to the Accession of King Alfred. Philadelphia : RichardWest, 1892 .

For a compelling attempt to reclaim a voice for Anglo-Saxon women, see Christine Fell's Women in Anglo-Saxon England and the Impact of 1066 (1984). Fell's central claim builds on the work of Doris Stenton (1957) and states that Anglo-Saxon women enjoyed a fairly high status and independence, which deteriorated sharply only after the Norman Conquest.
Chadwick, H. Munro and K. Kershaw Chadwick, "The Heroic Milieu." The Growth of Literature: Volume I: The Ancient Literatures of Europe. Cambridge: Cambridge University Press, 1932, pp. 64-79.

Connell, R.W., Gender and Power: Society, the Person and Sexual Politics. Stanford: Stanford UP, 1987.

Damico, Helen and Alexandra Hennessey Olsen, Introduction. New Readings on Women in Old English Literature. Ed. Helen Damico and Alexandra Hennessey Olsen. Blooming ton and Indianapolis: Indiana University Press, 1990, pp. 126.

Fell, Christine, Women in Anglo-Saxon England and the Impact of 1066. Cambridge: Colonnade, 1984

Klink, Anne L., The Old English Elegies: A Crifical Edition and Genre Study. Montreal etc. McGill-Queen's University Press, 1992.

Mandel, Jerome, "The Wife's Lament." Alternative Readings in Old English Poetry. New York etc.: Peter Lang, 1987, pp. 149-173.

Mitchell, Bruce, "The Narrator of "The Wife's Lament." Neuphilologische Mitteilungen, 73.(1972), pp. 222-234

Reichhardt, Ulf and Sabine Sielke, "What Does Man Want? The Recent Debates on Manhood and Masculinities." Amerikastudien/American Studies, 43:4 (1998), pp. $563-575$.

Renoir, Alain, "A Reading Context for The Wife's Lament." Anglo-Saxon Poetry: Essays in Appreciation. Festschrift for John C. McGalliard. Ed. Lewis E. Nicholson and Dolores Warwick Frese. London: University of Notre Dame Press, 1975, pp. 224-241.

Röder, Fritz, Die Familie bei den Angelsachsen: Eine Kultur- und Literarhistorische Studie auf Grund gleichzeitiger Quelle. Halle 1899.

Schücking, L.L.. "Das angelsächsische Gedicht von der "Klage der Frau." Zeitschrift fùr deutsches Altertum und deutsche Literatur, 48.(1906), pp. 436-449.

Sieper, Ennst, Die altenglische Elegie. Strassburg: Trübner, 1915

Stenton, Doris Mary, The English Woman in History. London: George Allen \& Unwin, 1957.

Stevens, Martin. "The Narrator of "The Wife's Lament." Neuphilologische Mitteilungen, 69 (1968), pp. $72-90$

Wentersdorf, Karl P. "The Situation of the Narxator in the Old English Wife's Lament," Old English Shorter Poems: Basic Readings. Ed. Katherine O'Brien O'Keefe. New York and London: Garland, 1994, pp. 357-392.

Whitelock, Dorothy, ed. Anglo-Saxon Wills. Cambridge: Cambridge University Press, 1930. 
Therese Steffen (Hrsg.)

\section{Masculinities - Maskulinitäten \\ Mythos - Realität - \\ Repräsentation - Rollendruck}

Verlag J. B. Metzler

Stuttgart · Weimar 